\title{
Penerapan Discovery Learning untuk Meningkatkan Efikasi Diri dan HOTS pada Tema Daerah Tempat Tinggalku Siswa Kelas IV A MIN 1 Kota Bengkulu
}

\author{
Sumini \\ Program Magister Pendidikan Dasar Universitas Bengkulu \\ sumini.jito@gmail.com \\ Endang Widi Winarni \\ Program Magister Pendidikan Dasar Universitas Bengkulu \\ Irwan Koto \\ Program Magister Pendidikan Dasar Universitas Bengkulu
}

\begin{abstract}
The objectives of this research to improve students' selff efficacy and HOTS. This research was a classroom action research done in 3 cycles performed, each cycle was consist of four stages namely: planning, acting, observing, and reflecting. The action research was done in class IVA, consist of 34 students, 16 female students, and 18 male students. The data were collected by an observation sheet, a questionnaire, and a test of HOTS. Then, the data were analyzed by avarage, percentage, and classification. The results of research showed that the teaching activity, self efficacy, HOTS were improved, and discovery learning effectively improve students' HOTS. Reccomendation of this research were: 1) the teachers should guide and correct the students' work, then encourage, reinforcement, even giving reward to students; 2) the teachers should direct the students to develop the knowledge to the environment activity, and inrease references; 3) the teachers should guide the students to connect the answers to their daily experiment; and 4) for the further research, reccommended to conduct the spesific about ability of students' to answer the question by creation using discovery learning.
\end{abstract}

Key Words: Discovery Learning, Self Efficacy, and HOTS

\section{Pendahuluan}

Perubahan sistem pendidikan ditandai dengan perubahan kurikulum. Saat ini kurikulum yag berlaku adalah kurikulum Tahun 2013, yang menekankan pada 
penempatan siswa lebih manusiawi atau dikenal dengan istilah "memanusiakan manusia". Artinya bahwa dalam proses pembelajaran, harus mengutamakan penghargaan terhadap siswa, baik dari keragaman karakteristik siswa, evaluasi seluruh potensi siswa dan yang lebih penting lagi mencintai siswa sepenuh hati.

Kurikulum 2013 menekankan adanya peningkatan dan keseimbangan aspek kompetensi sikap, keterampilan, dan pengetahuan, yang diikuti dengan peningkatan kemampuan dalam berpikir. Jika selama ini, siswa (khususnya pada jenjang Sekolah Dasar) hanya ditekankan pada kompetensi berpikir tingkat rendah, maka pada kurikulum yang berlaku saat ini, siswa diharuskan memiliki kompetensi berpikir tingkat tinggi. Secara umum, kemampuan berpikir merupakan klasifikasi kemampuan berpikir pada Taxonomi Bloom dalam Anderson dan Krathwohl (2010: 400), yaitu kemampuan berpikir tingkat rendah atau low order thinking skill disingkat LOTS (untuk selanjutnya akan menggunakan singkatan), dan kemampuan berpikir tingkat tinggi atau high order thinking skill, disingkat HOTS (untuk selanjutnya akan menggunakan singkatan).

Peran penting HOTS dalam pembelajaran siswa Sekolah Dasar terletak pada proses pembelajaran, karena ciri utama keterampilan berpikir tingkat tinggi adalah berpikir kritis dan kreatif (Conklin dalam Hidayati, 2017: 144). Dengan menerapkan HOTS, siswa akan terbiasa berpikir kritis dan kreatif baik dalam pengambilan keputusan maupun pemecahan masalah yang berkaitan dengan menganalisis, mengevaluasi dan mencipta (Anderson \& Krathwohl, 2010: 400). Jika siswa terbiasa dengan kegiatan menganalisis, mengevaluasi dan mencipta tersebut, maka dapat menunjang prestasi akademik siswa (Conklin dan Manfro dalam Hidayati, 2017: 144). Hal ini juga sejalan dengan tuntutan kurikulum 2013 yaitu menjadikan siswa lebih kritis dan kreatif, oleh sebab itu sangat penting sekali untuk melatih HOTS siswa sekolah dasar.

Sejak diterapkannya kurikulum 2013 pada Tahun ajaran 2016/2017 di MIN 1 Kota Bengkulu, HOTS siswa masih sangat rendah. Hal ini dapat dilihat dari hasil ulangan harian tema 3 (ayo cintai lingkungan) pada semester ganjil 2017/2018 siswa kelas IVA. Nilai rata-rata yang diperoleh hanya mencapai 67, yang artinya bahwa nilai tersebut belum termasuk kategori tuntas karena nilai kriteria ketuntasan maksimal (KKM) yang ditentukan adalah 70 . Dalam menjawab soal ulangan yang berupa soal essay tersebut, 24 dari 34 siswa hanya menjawab pertanyaan dengan jawaban pendek tanpa ada analisa, tanpa menghubungkan beberapa pengertian dalam materi, tidak ada upaya untuk menduga berbagai kemungkinan jawaban, dan tidak melakukan pemeriksaan secara cermat untuk membuktikan benar atau tidaknya jawaban yang ditulis.

Rendahnya HOTS siswa juga terlihat ketika proses pembelajaran, ketika guru bertanya kepada siswa tentang materi, 26 dari 34 siswa belum mampu menyatakan atau mempresentasikan jawaban, menanggapi jawaban, menjelaskan jawaban dalam bentuk argumen-argumen yang kuat. Siswa juga belum bisa membuat kesimpulan dari beberapa pendapat lain. Jikapun ada beberapa siswa (3 siswa) yang sudah bisa membuat kesimpulan, namun siswa tersebut belum mampu memberikan alasan atas kesimpulan yang dibuat. Hal ini berbanding terbalik dengan kebutuhan yang harus dipenuhi siswa dalam rangka mengembangkan kemampuan berpikir seperti yang diungkapkan oleh Abdullah (2017: 4) bahwa setiap siswa sejak dari level sekolah dasar harus memenuhi kriteria dalam pengembangan HOTS.

Selanjutnya, melalui pengamatan dan pengalaman peneliti selama mengajar, ada beberapa faktor yang menyebabkan rendahnya HOTS siswa, antara lain faktor internal dan eksternal. Menurut Syah (2011: 145) faktor internal merupakan faktor yang berasal dari dalam diri siswa itu sendiri, sedangkan faktor eksternal adalah faktor yang berasal dari luar diri siswa atau berasal dari lingkungan, baik lingkungan sosial maupun non sosial.

Salah satu faktor internal siswa yang berkaitan dengan HOTS adalah efikasi

diri. Menurut Bandura (1999: 119) keterlibatan, motivasi dan keter- 
tarikan siswa pada materi yang diberikan sebagai faktor perilaku yang mempengaruhi berpikir kritis dan atau berpikir tingkat lebih tinggi, bergantung pada affective dan cognitive seperti efikasi diri, sebagai faktor pribadi (personal). Efikasi diri merupakan hasil dari proses kognitif seseorang berupa suatu keyakinan akan seberapa besar kemampuannya dalam melakukan dan menyelesaikan suatu tugas tertentu (Bandura, 1999: 121). Efikasi diri yang tinggi membuat seseorang yakin akan seberapa besar kemampuannya dan akan menghasilkan bentuk perilaku terlibat, termotivasi, dan tertarik pada materi yang diberikan yang pada akhirnya akan dapat meningkatkan kemampuan berpikir siswa.

Rendahnya HOTS dan efikasi diri siswa cenderung berbanding lurus. Siswa yang memiliki HOTS rendah cenderung memiliki efikasi diri rendah, yang dapat dilihat dari rendahnya kepercayaan akan kemampuannya dalam menyelesaikan tugas seperti menghindari untuk mengerjakan soal-soal yang sulit atau mudah menyerah dalam mengerjakan tugas yang sulit, tidak suka dengan tantangan dalam mengerjakan tugas, dan tidak mampu mengerjakan soal yang bervariasi. Kecenderungan tersebut sesuai dengan hasil penelitian Basito, Arthur, dan Daryati (2018: 12) yang menyimpulkan bahwa terdapat hubungan positif antara efikasi diri dan berpikir tingkat tinggi. Berdasarkan analisis diketahui bahwa jumlah siswa yang efikasi dirinya rendah dan sangat rendah bersesuaian dengan jumlah siswa yang memiliki berpikir tingkat tinggi rendah dan sangat rendah. Hal yang sama juga terjadi pada efikasi diri yang tinggi dan sangat tinggi, dimana jumlahnya bersesuaian dengan berpikir tingkat tinggi tinggi dan sangat tinggi.

Sementara itu, faktor eksternal atau faktor dari luar yang mempengaruhi HOTS berkaitan dengan proses pembelajaran. Hal ini berkenaan dengan model atau metode pembelajaran yang digunakan guru. Berdasarkan pada kemampuan berpikir sebagai proses kemampuan yang bisa dilatih, maka dengan menciptakan suasana pembelajaran yang kondusif akan merangsang siswa untuk meningkatkan kemampuan berpikir. Dengan alasan itu, guru diharapkan dapat mencari metode, model, dan strategi pembelajaran yang dampaknya dapat meningkatkan HOTS.

Salah satu pembelajaran yang dapat mencapai tujuan penelitian ini adalah pembelajaran discovery learning. Menurut Anam (2015: 110) pembelajaran discovery learning dapat meningkatkan kemampuan HOTS dan efikasi diri siswa karena pada pembelajaran ini memberikan kesempatan kepada siswa untuk menggunakan kemampuan berpikir dalam penyelidikan terhadap konsep yang disajikan dalam upaya memecahkan masalah.

Pembelajaran discovery learning ini terbukti dapat meningkatkan kemampuan HOTS dan efikasi diri, seperti hasil penelitian yang dilakukan oleh Zainuddin (2016: 368) yang menyimpulkan bahwa efektivitas penerapan pembelajaran dalam meningkatkan HOTS termasuk dalam kategori efektif, sebesar 75,5\%, sedangkan penelitian yang dilakukan oleh Hugerat dan Kortam (2014: 452) menunjukkan bahwa pembelajaran penemuan dapat meningkatkan HOTS siswa. Sementara itu, hasil penelitian Fajri, Johar, dan Ikhsan (2016: 194) menunjukkan bahwa model pembelajaran discovery learning efektif untuk meningkatkan efikasi diri siswa.

\section{Metode}

Jenis penelitian yang digunakan dalam penelitian ini merupakan penelitian tindakan kelas (PTK). Maharani (2014: 21) mendefinisikan PTK sebagai suatu pengamatan dengan menerapkan tindakan di dalam kelas menggunakan aturan yang sesuai dengan metodologi penelitian yang dilakukan dalam beberapa periode atau siklus. Penelitian tindakan kelas ditandai dengan adanya perbaikan terus menerus, sehingga tercapai sasaran dari penelitian.

Tahapan-tahapan pelaksanan PTK model Hopkins dalam Maharani (2014: 22) adalah perencanaan, pelaksanaan, pengamatan, dan refleksi. Jumlah siklus yang akan dilaksanakan dalam penelitian ini tergantung pada pencapaian tujuan 
penelitian. Jika pada siklus kedua tercapai pencapaian tujuan maka penelitian berhenti pada siklus kedua, jika belum tercapai maka akan dilanjutkan ke siklus berikutnya.

Penelitian ini dilaksanakan di MIN 1 Kota Bengkulu, yang terletak di Jalan Irian nomor 40 Kelurahan Semarang Kota Bengkulu. MIN 1 Kota Bengkulu. Subjek dalam penelitian ini adalah siswa kelas IVA MIN 1 Kota Bengkulu tahun ajaran 2017/2018 sebanyak 34 siswa yang terdiri atas 16 siswa perempuan dan 18 siswa laki-laki. Pemilihan kelas ini didasarkan pada pertimbangan bahwa pada saat pra penelitian, permasalahan ditemukan pada kelas tersebut yaitu masih rendahnya HOTS dan efikasi diri siswa.

Teknik pengumpulan data dalam penelitian ini melalui observasi, angket dan tes. Lembar observasi digunakan untuk mendapatkan data mengenai pelaksanaan pembelajaran. Lembar angket digunakan untuk menilai efikasi diri. Penilain efikiasi diri dilakukan oleh penilai pada saat proses pembelajaran. Lembar angket efikasi diri terdiri atas 20 pernyataan yang diambil dari indikator-indikator efikasi diri yang disesuaikan dengan aspek-aspek efikasi diri berdasarkan teori Bandura (1986: 68). Sementara itu, tes digunakan untuk mengukur HOTS siswa. Tes terdiri atas 5 soal essay yang disesuaikan dengan materi pelajaran pada tema 8 yaitu daerah tempat tinggalku.

Selanjutnya data dianalisis dengan menggunakan rumus nilai rata-rata, kemudian diklasifikasikan ke dalam kategori yang telah ditentukan. Penelitian ini dikatakan berhasil jika memenuhi indikator keberhasilan tindakan berikut:

1. Tindakan dinyatakan berhasil jika aktivitas pembelajaran siswa secara rata-rata dalam kategori baik.

2. Tindakan dinyatakan berhasil jika secara rata-rata efikasi diri siswa dalam kategori tinggi.

3. Siswa dinyatakan berhasil secara individual jika memperoleh nilai HOTS dengan rata-rata kelas mencapai $\geq 70$, dan secara klasikal jika $85 \%$ siswa memperoleh nilai rata-rata $\geq 70$.

4. Penerapan pembelajaran discovery learning dikatakan efektif jika dapat meningkatkan HOTS siswa pada kelas pembanding (IVB) MIN 1 Kota Bengkulu.

\section{Hasil}

Hasil penelitian mengenai penerapan discovery learning pada pembelajaran tema daerah tempat tinggalku siswa kelas IVA MIN 1 Kota Bengkulu dilihat dari aktivitas pembelajaran siswa, efikasi diri, dan nilai HOTS.

\section{Hasil Penelitian Siklus 1}

Berdasarkan hasil analisis, secara keseluruhan penilaian aktivitas pembelajaran termasuk dalam kategori "cukup" dengan rata-rata 11,97. Dari 34 siswa, 10 siswa (29,5\%) memperoleh nilai dengan kategori "baik", 20 siswa $(58,8 \%)$ memperoleh nilai dengan kategori "cukup", dan 4 siswa $(11,7 \%)$ memperoleh nilai dengan kategori "kurang".

Sementara itu, berdasarkan hasil analisis, nilai efikasi diri menunjukkan rata-rata efikasi diri siswa adalah 54,55 yang termasuk dalam kategori "rendah". Tidak ada siswa yang memperoleh nilai dengan kategori "sangat rendah", 17 siswa (50\%) memperoleh nilai dengan kategori "rendah", 14 siswa (41,2\%) memperoleh nilai dengan kategori "sedang", 3 siswa (8,8\%) memperoleh nilai yang termasuk dalam kategori "tinggi", dan tidak ada siswa yang memperoleh nilai yang termasuk dalam kategori "sangat tinggi".

Selanjutnya, untuk rata-rata nilai HOTS siswa adalah 51,29 yang termasuk dalam kategori "rendah". Sebanyak 2 siswa $(5,8 \%)$ dari 34 siswa memperoleh nilai yang termasuk kategori "sangat rendah", 20 siswa (58,9\%) memperoleh nilai dengan kategori "rendah", 10 siswa $(29,5 \%)$ memperoleh nilai dalam kategori "sedang", 2 
siswa $(5,8 \%)$ memperoleh nilai yang termasuk dalam kategori "tinggi", dan tidak ada siswa yang memperoleh nilai dalam kategori "sangat tinggi". Hasil HOTS siswa tersebut dapat dilihat pada Grafik 4.1.



\section{Grafik 4.1 Rekapitulasi Hasil HOTS Siswa Siklus I}

\section{Hasil Penelitian Siklus 2}

Hasil analisis menunjukkan bahwa aktivitas pembelajaran termasuk dalam kategori "baik" dengan rata-rata 15,14. Dari 34 siswa, 10 siswa (29,5\%) memperoleh nilai dengan kategori "baik", 20 siswa $(58,8 \%)$ memperoleh nilai dengan kategori "cukup", dan 4 siswa (11,7\%) memperoleh nilai yang termasuk dalam kategori "kurang".

Hasil perolehan nilai efikasi diri siklus II menunjukkan bahwa nilai ratarata efikasi diri siswa adalah 66,17 yang termasuk dalam kategori "sedang". Tidak ada siswa yang memperoleh nilai dalam kategori "sangat rendah", 11 siswa (32,4\%) memperoleh nilai dengan kategori "rendah", terdapat 10 siswa $(29,4 \%)$ memperoleh nilai dalam kategori "sedang", 10 siswa $(29,4 \%)$ memperoleh nilai dengan yang termasuk dalam kategori "tinggi", dan 3 siswa (8,8\%) memperoleh nilai yang termasuk dalam kategori "sangat tinggi".

Hasil perolehan penilaian HOTS menunjukkan bahwa rata-rata nilai HOTS siswa adalah 62,91 yang termasuk dalam kategori "sedang". Tidak ada siswa yang memperoleh nilai yang termasuk kategori "sangat rendah", 5 siswa $(14,7 \%)$ memperoleh nilai dengan dengan kategori "rendah", 15 siswa (44,2\%) memperoleh nilai dalam kategori "sedang", 12 siswa $(35,3 \%)$ memperoleh nilai yang termasuk dalam kategori "tinggi", dan 2 siswa $(5,8 \%)$ yang memperoleh nilai yang termasuk dalam kategori "sangat tinggi". Hasil HOTS siswa tersebut dapat dilihat pada Grafik 4.1 .

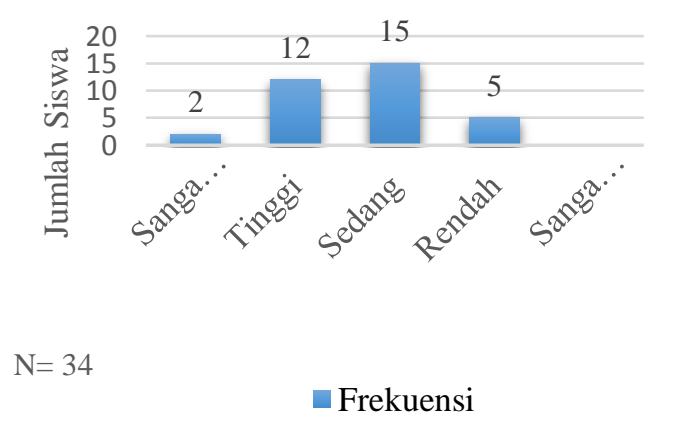

\section{Grafik 4.4 Rekapitulasi Hasil HOTS Siswa Siklus II}

Hasil Penelitian Siklus 3

Berdasarkan hasil analisis, keseluruhan aktivitas siswa termasuk dalam kategori "sangat baik" dengan rata-rata 18,14. Dari 34 siswa, 16 siswa $(47,1 \%)$ memperoleh nilai dengan kategori "sangat baik", 16 siswa $(47,1 \%)$ memperoleh nilai kategori "cukup", dan tidak ada siswa yang memperoleh nilai yang termasuk dalam kategori "kurang". 
Data hasil perolehan penilaian efikasi diri siswa menunjukkan bahwa rata-rata efikasi diri siswa adalah 74,41 yang termasuk dalam kategori "tinggi". Tidak ada siswa yang memperoleh nilai yang termasuk kategori "sangat rendah", 3 siswa $(8,8 \%)$ memperoleh nilai dengan kategori "rendah", 4 siswa $(11,8 \%)$ memperoleh nilai dengan kategori "sedang", 20 siswa $(58,8 \%)$ memperoleh nilai yang termasuk dalam kategori "tinggi", dan 7 siswa (20,6\%) memperoleh nilai yang termasuk dalam kategori "sangat tinggi".

Dari 34 siswa, tidak ada siswa yang memperoleh nilai yang termasuk kategori "sangat rendah", tidak ada siswa yang memperoleh nilai dengan kategori "rendah", sebanyak 3 siswa (8,8\%) memperoleh nilai dalam kategori "sedang", 26 siswa $(76,5 \%)$ memperoleh nilai yang termasuk dalam kategori "tinggi", dan 5 siswa (14,7\%) memperoleh nilai yang termasuk dalam kategori "sangat tinggi". Nilai perolehan HOTS siswa tersebut disajikan pada Grafik 4.4.

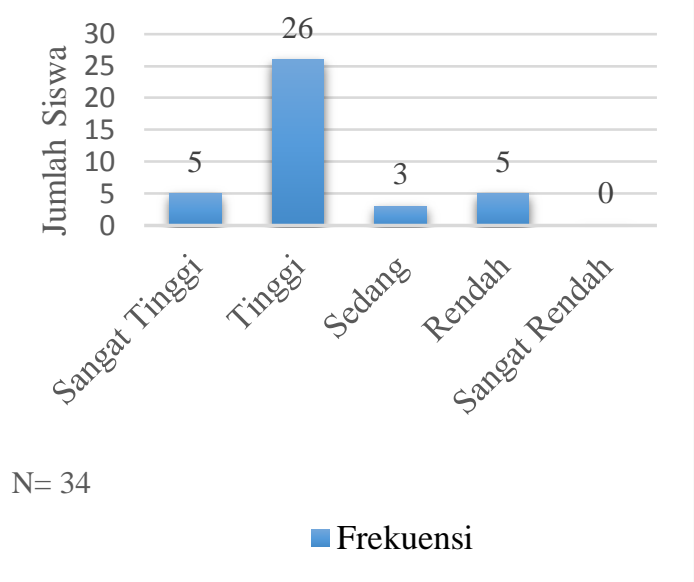

\section{Grafik 4.4 Rekapitulasi Hasil HOTS Siswa Siklus III}

\section{Pembahasan}

Hasil analisis perhitungan data untuk nilai rata-rata aktivitas pembelajaran termasuk dalam kategori "cukup" dengan rata-rata 11,97. Perolehan nilai aktivitas belajar tersebut mengindikasikan bahwa aktivitas siswa dan guru dalam pembelajaran dengan menerapkan discovery learning masih belum maksimal. Hal ini bisa disebabkan karena siswa kurang menyenangi pembelajaran ini, padahal menurut Budiningsih (2007: 44) salah satu kelebihan pembelajaran discovery learning menimbulkan rasa senang pada siswa. Dengan timbulnya rasa senang, maka akan mudah menumbuhkan motivasi diri sendiri siswa, sehingga proses mengembangkan kemampuan berpikir siswa ke arah berpikir tingkat tinggi dapat berjalan dengan baik.

Selanjutnya, pada siklus I rata-rata efikasi diri siswa adalah 54,55 yang termasuk dalam kategori "rendah", sedangkan rata-rata nilai HOTS siswa adalah 51,29 yang juga termasuk dalam kategori "rendah". Hal ini mengindikasikan bahwa adanya kecenderungan tingkat efikasi diri siswa berbanding lurus dengan HOTS siswa. Artinya bahwa siswa yang memiliki tingkat efikasi diri rendah, juga memiliki tingkat HOTS yang rendah. Hal ini sesuai dengan pendapat Bandura (1999: 130) bahwa seseorang yang kuat efikasi dirinya akan meningkatkan prestasi pribadi dan kesejahteraannya dalam berbagai strategi. Siswa yang memiliki efikasi tinggi akan cenderung untuk memilih tugas yang menantang dan gigih dalam menghadapi suatu tantangan baru serta akan berusaha lebih keras untuk mencapai tujuan, ini menunjukkan bahwa siswa yang memiliki efikasi diri tinggi akan berusaha berpikir lebih tinggi dan lebih optimis dan selalu mencoba mencari solusi pemecahan tugas-tugas yang sulit.

Rata-rata nilai aktivitas pembelajaran pada siklus II sebesar 15,14 termasuk dalam kategori "tinggi”. Berdasarkan refleksi pada siklus II peningkatan 


\section{Penerapan Discovery Learning untuk Meningkatkan Efikasi Diri dan Hots pada Tema Daerah Tempat Tinggalku Siswa Kelas IV A Min 1 Kota Bengkulu}

aktivitas pembelajaran pada siklus II, masih ditemukan beberapa kekurangan antara lain pada langkah mengolah data, yaitu saat siswa diminta menganalisis perbedaan karakter tokoh-tokoh pada cerita fiksi (tokoh utama dan tokoh tambahan), dan siswa diminta menganalisis karakteristik tokoh-tokoh yang ada pada cerita fiksi (tokoh utama dan tokoh tambahan). Jawaban yang dibuat siswa untuk dua aktivitas tersebut hampir sama. Hal ini menunjukkan kurangnya kemampuan siswa dalam mengembangkan kalimat yang menunjukkan karakteristik dan perbedaan karakteristik tokoh-tokoh. Dengan kata lain siswa kurang memahami petunjuk kegiatan atau siswa tidak bisa membedakan antara pengertian perbedaan dan pengertian karakteristik itu sendiri. Hal ini tidak sesuai dengan pendapat yang diungkapkan oleh Anam (2015: 110) bahwa tujuan lain pembelajaran discovery learning menurut adalah untuk mendorong siswa agar semakin berani dan kreatif berimajinasi. Dengan imajinasi siswa dibimbing untuk mengkreasi sesuatu menggunakan pengetahuan yang diperolehnya.

Kekurangan yang dihadapi siswa pada siklus II adalah kesulitan siswa dalam menjawab soal yang berhubungan dengan memberikan pendapat atau alasan (pertanyaan diawali dengan mengapa), dan siswa tidak menuliskan jawaban lengkap jika diminta membuat kesimpulan. Hal ini bertentangan dengan pendapat yang diungkapkan oleh Anam (2015: 110) bahwa pembelajaran discovery learning bertujuan agar siswa mampu merumuskan dan menjawab pertanyaan apa, siapa, kapan, dimana, mengapa, dan bagaimana, karena discovery learning membantu siswa mengasah kemampuan berpikir, baik berpikir tingkat rendah maupun berpikir tingkat tinggi.

Peningkatan efikasi diri pada siklus III dapat dilihat dari perbaikan jawaban pada pernyataan "saya mau mengerjakan tugas walaupun sulit", dan "saya mau mengerjakan soal-soal yang lebih luas dan bervariasi", dimana pada siklus III, pernyataan tersebut sebagian besar dijawab "ya" oleh siswa. Artinya bahwa siswa sudah memiliki keinginan dalam mengerjakan sesuatu yang dianggap sulit, dan siswa cenderung menyukai tantangan dalam mengerjakan sesuatu yang lebih sulit. Hal ini sesuai dengan pendapat Ball dan Garton dalam Munira dan Zakaria (2017) bahwa penggunaan pikiran secara lebih luas dalam menemukan tantangan baru dengan mengeksplorasi pengalaman yang kompleks, reflektif dan kreatif yang dilakukan secara sadar untuk mencapai tujuan, yaitu memperoleh pengetahuan yang meliputi tingkat berpikir analitis, sintesis, dan evaluasi, dan inovasi. Artinya bahwa kemampuan berpikir tingkat tinggi tidak hanya membutuhkan kemampuan mengingat saja, namun membutuhkan kemampuan lain yang lebih tinggi, seperti kemampuan berpikir kreatif dan kritis.

Penerapan pembelajaran discovery learning efektif dalam meningkatkan HOTS siswa kelas IV MIN 1 Kota Bengkulu. Hal ini dapat dilihat dari nilai persentase selisih (gain) nilai HOTS siswa siklus III dengan nilai HOTS siswa kelas pembanding. Perbedaan nilai tersebut tidak signifikan. Hal ini mengindikasikan bahwa pembelajaran discovery learning efektif dalam meningkatkan HOTS siswa kelas IV MIN 1 Kota Bengkulu. Hal ini sesuai dengan pendapat yang diungkapkan oleh Budiningsih (2007: 43) bahwa keunggulan dari pembelajaran discovery learning adalah membantu siswa meningkatkan keterampilan kogitif, dapat menguatkan pengertian, ingatan dan transfer ilmu, dan mengembangkan kemampuan berpikir siswa ke arah berpikir tingkat tinggi. Hasil penelitian tersebut juga sejalan dengan pendapat yang diungkapkan oleh Kurniawan dalam Winarni (2018: 190) bahwa salah satu tujuan pembelajaran discovery learning adalah membantu siswa menemukan konsep-konsep dan prinsip-prinsip yang dipelajari melalui penemuan lebih bermakna.

Berdasarkan perolehan nilai rata-rata untuk aktivitas pembelajaran sebesar 18,14 termasuk dalam kategori "sangat tinggi", sedangkan untuk nilai rata-rata efikasi diri siswa sebesar 74,41 juga dengan kategori "tinggi", dan nilai rata-rata HOTS siswa secara individual adalah 75.08, yang termasuk dalam kategori "tinggi". Peningkatan nilai HOTS tersebut, sesuai dengan pendapat yang diungkapkan oleh 
Winarni (2018: 261) bahwa dengan HOTS siswa dapat membedakan ide atau gagasan secara jelas, berargumen dengan baik, mampu memecahkan masalah, mampu mengkonstruksi penjelasan, mampu berhipotesis dan memahami hal-hal kompleks menjadi lebih jelas.

Hasil penelitian tersebut juga sejalan dengan hasil penelitian yang dilakukan oleh Zainuddin (2016), Hugerat dan Kortam (2014), dan Nurhayati (2014). Hasil penelitian oleh Zainuddin (2016) menyimpulkan bahwa model pembelajaran discovery learning terbukti dapat meningkatkan kemampuan HOTS dan efikasi diri. Sementara itu, penelitian yang dilakukan oleh Hugerat dan Kortam (2014) menunjukkan bahwa pembelajaran penemuan dapat meningkatkan HOTS siswa, dan hasil penelitian Nurhayati (2014) menunjukkan bahwa model pembelajaran discovery learning efektif untuk meningkatkan efikasi diri siswa.

Sehubungan dengan uraian mengenai peningkatan aktivitas pembelajaran, efikasi diri, dan HOTS siswa dengan menerapkan discovery learning, maka dapat disimpulkan bahwa pembelajaran dengan menerapkan discovery learning telah berhasil, sehingga tidak perlu dilakukan pelaksanan siklus berikutnya. Hal tersebut mem-perkuat dan memastikan bahwa penerapan discovery learning dapat meningkatkan efikasi diri dan HOTS siswa kelas IVA MIN I Kota Bengkulu.

\section{Kesimpulan}

Berdasarkan hasil penelitian dan pembahasan, maka dapat ditarik kesimpulan sebagai berikut:

1. Penerapan discovery learning pada pembelajaran tema daerah tempat tinggalku dapat meningkatkan aktivitas pembelajaran siswa kelas IVA MIN 1 Kota Bengkulu. Peningkatan aktivitas pembelajaran dutunjukkan dari peningkatan rata-rata aktivitas pembelajaran pada tiap-tiap siklusnya.

2. Penerapan discovery learning dapat meningkatkan efikasi diri siswa kelas IVA MIN 1 Kota Bengkulu. Peningkatan efikasi diri diketahui dari peningkatan rata-rata efikasi diri pada tiap-tiap siklusnya.

3. Penerapan discovery learning dapat meningkatkan HOTS siswa kelas IVA MIN 1 Kota Bengkulu. Peningkatan tersebut diketahui dari peningkatan nilai ratarata HOTS siswa tiap-tiap siklus pada aspek analisis, evaluasi, dan kreasi.

4. Penerapan pembelajaran discovery learning efektif dalam meningkatkan HOTS siswa kelas IV MIN 1 Kota Bengkulu. Hal ini dapat dilihat dari nilai persentase selisih (gain) nilai HOTS siswa kelas discovery learning dengan nilai HOTS siswa kelas pembanding.

\section{Saran}

Berdasarkan kesimpulan yang telah dikemukakan, untuk mengkaji lebih lanjut hasil penelitian ini, maka peneliti mengajukan beberapa saran sebagai berikut:

1. Hasil analisis menunjukkan bahwa dua aktivitas pembelajaran discovery learning pada tahap pembuktian dan membuat kesimpulan untuk tiap-tiap siklus lebih rendah dibandingkan dengan tahap stimulasi, identifikasi masalah, mengumpulkan data, dan mengolah data, disarankan kepada guru untuk memberikan bimbingan dan terbuka dalam memberikan koreksian terhadap hasil penyelidikan siswa, dan menanamkan rasa percaya diri siswa terhadap penemuan yang dihasilkan dengan memberikan motivasi, penguatan, bahkan reward.

2. Berdasarkan pada hasil analisis yang menunjukkan aspek penilaian efikasi diri (aspek generalitas) lebih rendah dibandingkan dua aspek penilain lainnya, yang dapat dilihat dari rendahnya keinginan siswa untuk mengerjakan soal-soal, disarankan kepada guru untuk lebih menekankan pada membuka wawasan siswa yang berhubungan dengan materi, menghubungkan materi dengan kejadian di 
lingkungan sehari-hari.

3. Hasil analisis menunjukkan bahwa penilaian HOTS pada aspek mengkreasi lebih rendah dibandingkan dengan aspek analisis dan evaluasi, disarankan kepada guru untuk membimbing siswa agar mampu mengkreasikan jawaban dengan berbagai pengalaman yang dimiliki dan menghubungkan jawaban soal pada kejadian di lingkungan sehari-hari.

4. Pada penelitian ini ditemukan aspek penilaian HOTS mengkreasi lebih sulit diterapkan oleh siswa, untuk penelitian selanjutnya disarankan melakukan penelitian yang lebih spesifik tentang kemampuan menjawab soal dengan kreasi melalui discovery learning.

\section{Referensi}

Anam, K. (2015). Pembelajaran Berbasis Inkuiri Metode dan Aplikasi. Yogyakarta: Pustaka Pelajar.

Anderson, O.W. dan Krathwohl, D.R. (2010). A Taxonomy for Learning, Teaching, and Assessing: A Revision of Bloom's Taxonomy of Educational Objectives. New York: Longman.

Bandura, A. (1986). Social foundations of thought and action: A social cognitive theory. Englewood Cliffs, NJ: Prentice-Hall.

Bandura A. (1999). Perceived Self-Efficacy in Cognitive Development and Functioning. Educational Psychologis Stanford University, Lawrence Elbaum Associates, Inc. 28 (2), 117-148.

Basito, D. M., Arthur, R., Daryati. (2018). Hubungan Efikasi Diri Terhadap Kemampuan Berpikir Tingkat Tinggi Siswa SMK Program Keahlian Teknik Bangunan pada Mata Pelajaran Mekanika Teknik. Jurnal Pendidikan Teknik Sipil, Volume 7, No 1: 2-14.

Budiningsih, C.A. (2007). Belajar dan Pembelajaran. Jakarta: PT Rineka Cipta.

Fajri, N.H., Johar, R., Ikhsan, M. (2016). Peningkatan Kemampuan Spasial Dan Self-Efficacy Siswa Melalui Model Discovery Learning Berbasis Multimedia. Jurnal Tadris Matematika, Vol. 9 No. 2 (Nopember) 2016, Hal.180-196.

Hidayati, U.A. (2017). Melatih Kemampuan Berpikir Tingkat Tinggi dalam Pelajaran Matematika pada Siswa Sekolah Dasar. TERAMPIL, Jurnal Pendidikan dan Pembelajaran Dasar, Volume 4 Nomor 2: 143-156.

Hugerat, M dan Kortam, N. (2015). Improving HOTS among Freshmen by Teaching Science through Inquiry. Journal of Technical Education and Training (JTET). Vol 7 (2): 35-43.

Maharani, E. (2014). Pembelajaran Tematik. Yogyakarta: Parasmu.

Munira, M dan Zakaria, R. (2017). Inclusive Pedagogy Literacy among Academic Community at Institute of Teacher Education, Kuala Lumpur. Journal of Scientific Research Publishing, Vol 5: 114-122.

Nurhayati. (2014). Peningkatan Efikasi Diri dengan Menerapkan Model Pembelajaran Inquiry/Discovery Learning Siswa Kelas VII-G SMPN 07 Malang pada Materi Lembaga Sosial. Jurnal Interaksi, Vol. 1, No.1, 54-72. 
Penerapan Discovery Learning untuk Meningkatkan Efikasi Diri dan Hots pada Tema Daerah Tempat Tinggalku Siswa Kelas IV A Min 1 Kota Bengkulu

Winarni, E.W. (2018). Pendekatan Ilmiah dalam Pembelajaran Kreatif dan Inovatif Bengkulu: FKIP UNIB.

Zainuddin. (2016). Mengembangkan Keterampilan Berpikir Tingkat Tinggi melalui Pembelajaran IPA. Prosiding Seminar Nasional Pendidikan IPA, UNLAM PRESS. Edisi Oktober Tahun 2016; 361-368. ISBN: 978-602-60213-0-4 